Tectonophysics, 26 (1975) 281-292

(C) Elsevier Scientific Publishing Company, Amsterdam - Printed in The Netherlands

THE PALEOMAGNETISM OF THE SPECKLED SANDSTONES OF EARLY PERMIAN AGE FROM THE SALT RANGE, PAKISTAN

\author{
H. WENSINK
}

Geological Institute, State University Utrecht, Utrecht (The Netherlands)

(Submitted June 14, 1974; revised version accepted December 3, 1974)

\begin{abstract}
Wensink, H., 1975. The paleomagnetism of the Speckled Sandstones of Early Permian Age from the Salt Range, Pakistan. Tectonophysics, 26: 281-292.

Paleomagnetic results are presented from the Speckled Sandstones, of probably Early Permian age, from the Salt Range in Pakistan. The analysis includes 86 specimens from nine sites collected at three individual localities. All specimens were subjected to progressive, thermal treatment which revealed the characteristic directions of magnetization, with a mean value of $D=92.2^{\circ}, I=+46.7^{\circ}, \alpha_{95}=7.3^{\circ}$. The paleomagnetic pole is located at $13^{\circ} \mathrm{N}, 137.5^{\circ} \mathrm{E}$, with $\delta_{\mathfrak{p}}=5.1^{\circ}$ and $\delta_{m}=9.5^{\circ}$. This position agrees well with the paleomagnetic pole positions derived from Indian rocks of about the same age, thus giving no reason to postulate relative movements between the Salt Range and the Indian basement since the Carboniferous.
\end{abstract}

\title{
INTRODUCTION
}

The ravines at the southern escarpment of the Salt Range in Pakistan exhibit beautiful geological sections. In general, the rock sequence starts with an impressive suite of sediments of Cambrian age and up to $400 \mathrm{~m}$ thick, comprising salts, red silts and sandstones, shales and dolomites. A considerable hiatus exists between these sediments and the overlying detrital and calcareous deposits, which have Late Carboniferous and Permian age. Limestones of Eocene age cover the Upper Paleozoic rocks. Next follow the sediments of the Siwalik formation; these continental deposits of Miocene and Pliocene age are mainly exposed on the Potwar plateau (Fig. 1).

\section{PERMO-CARBONIFEROUS DEPOSITS}

In the Salt Range the basal layers of the sediments of Permo-Carboniferous age unconformably cover the rocks of the Cambrian.

In the stratigraphical description of the rocks in the Salt Range we mainly 


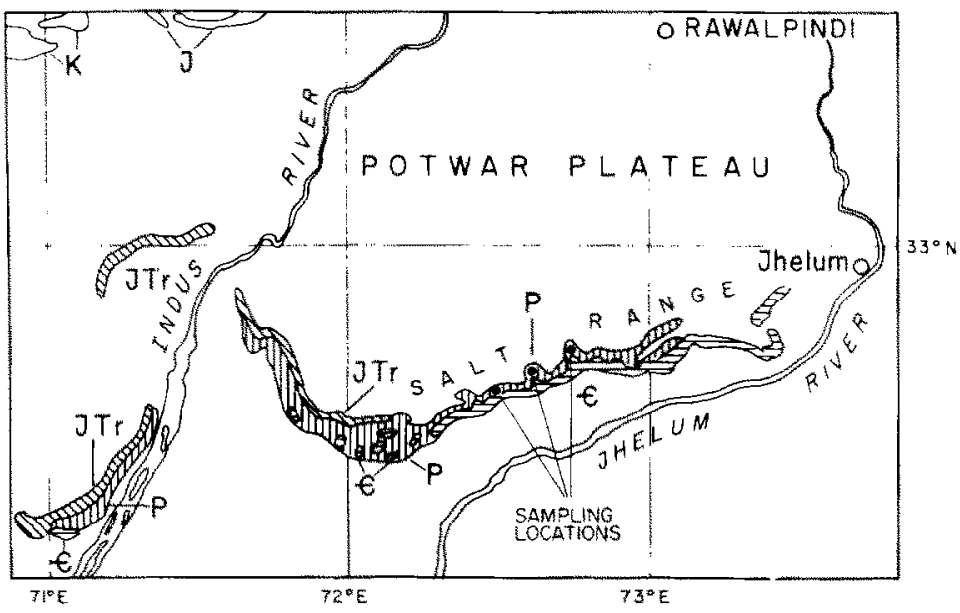

Fig. 1. Geological map of the Salt Range, Pakistan, with the sampling localities. The Tertiary and Quaternary deposits are not indicated.

follow Pascoe (1959). The sediments above the unconformity are combined in the Shahpur System, which is subdivided into the Nilawan Series with mainly detrital sediments and the overlying Productus Limestone Series with calcareous sediments (Fig. 2). The Nilawan Series contains four stages: The Talchir Beds; the Conularia Beds; the Speckled Sandstones; and the Lavender Clays. The lowermost stage, the Talchir Boulder Beds, contains completely unsorted

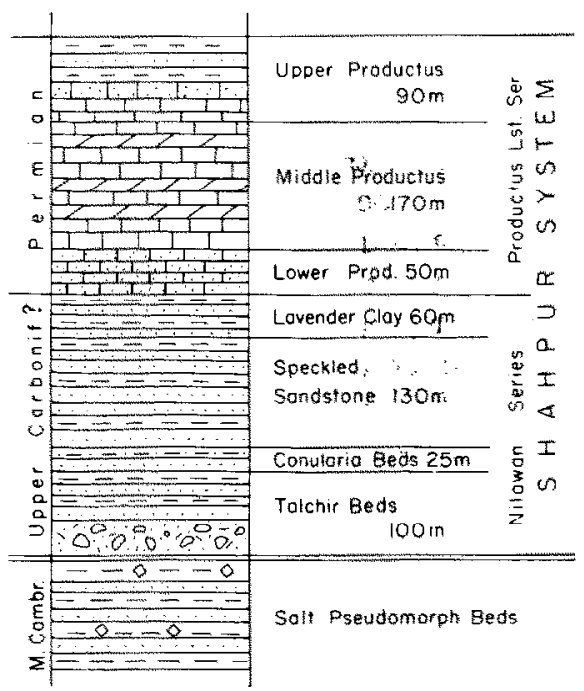

Fig. 2. Stratigraphical column of the rocks of Late Carboniferous and Permian age from the Salt Range. The thickness indicated at each stage is the maximum value. 
deposits with very fine to coarse components. The glacial character of this sediment is beyond doubt. The Talchir Beds, reaching a thickness of up to $100 \mathrm{~m}$ at most, are overlain by a $20 \mathrm{~m}$ thick series of green and brownish sandstones and shales of the Conularia Stage. The latter sediments yield a rich fauna: a large proportion of species is comparable with forms found in the oldest marine series in the Permo-Carboniferous of New South Wales, Australia, giving good reason to place the stage at the top of the Upper Carboniferous or in the lowermost Permian (see also Krishnan, 1960). The next stage, the Speckled Sandstones, shows a variety of red to brownish clays, shales, siltstones, and sandstones. These partly unconsolidated sediments, reaching a thickness of $70 \mathrm{~m}$ to more than $100 \mathrm{~m}$, are poorly fossiliferous. The uppermost stage of the Nilawan Series, the purple and green and about $50 \mathrm{~m}$ thick Lavender Clays, does not contain fossils.

The Productus Limestone Series is subdivided into three stages. Following the fossil records the successive stages roughly correspond with the Lower, the Middle, and the Upper Permian.

\section{THE AGE OF THE SHAHPUR SYSTEM}

Unfortunately, there is no agreement concerning the ages of the various stages of the Permo-Carboniferous rock sequence in the Salt Range.

The Talchir Boulder Beds, exposed both in Pakistan and in India, may be correlated with the Dwyka Tillite from Africa. On both continents evidence has been found for one glacial period only during the Late Paleozoic. The age of the Dwyka Tillite is usually regarded as Late Carboniferous, based on plant fossils (Du Toit, 1954). However, McElhinny and Opdyke (1968) have reported that the Dwyka deposits are Early rather than Late Carboniferous in age; the greater age is based on the discovery of plant fossils, among which Leptophloeum Australe, lying in sediments directly upon the Dwyka glacial beds. The paleomagnetic results of the Dwyka varves favour an Early Carboniferous age; then the data fit rather well in the Late Paleozoic polar wandering path of Africa, also if compared with the polar path of Australia. A rapid polar shift relative to Gondwanaland has taken place during the Carboniferous and Permian (see also Wensink, 1973, fig. 5). It is clear that a possible Early Carboniferous age for the African Dwyka Tillites obstructs the usual correlation between the glacial deposits of Africa and India-Pakistan. Moreover, in the Salt Range the sediments lying upon the Talchir Beds may be even younger than was previously accepted. In the opinion of Douglass (1970), who has studied the fusulinids of the Lower Productus Limestone, the age of this stage could be Late Permian. Palynological studies of the detrital Nilawan Series should also point to younger ages (Balme, 1970). According to Venkatachala and Kar (1968) the palynological assemblages of the Speckled Sandstones could indicate a Late Permian age for this stage. However, the newer results do not present definitive ages for the sediments of the Salt Range. Considering the data available, it seems justifiable at this time to accept an Early Permian age for the Speckled Sandstones. 


\section{SAMPLING}

For a paleomagnetic study, oriented samples were collected at three localities in the detrital rocks above the Talchir Beds. Along the Nurpur-Kushab road the sampling was carried out with a portable diamond drill provided with a coring tube of $2.5 \mathrm{~cm}$ inner diameter. At four sites 35 cores were collected in violet to brown fine-grained sandstones at a height of about 10$15 \mathrm{~m}$ above the Talchir Boulder Beds. This locality may be situated in the upper part of the Conularia Beds.

Elsewhere, core drilling was impossible because of both the steep slopes in the gorges and the soft character of the rocks. At four sites in the Nilawan gorge, oriented hand samples were taken from red clays, siltstones, and sandstones about halfway up in the Speckled Sandstones sequence. At two sites in the Sardahi gorge samples were obtained from brownish red sandstones located in the higher part of the stage.

\section{PALEOMAGNETIC PROCEDURES}

The material was investigated at the Paleomagnetic Laboratory of Utrecht State University. Cores of standard diameter were drilled out of the hand samples. The cores were sawn into cylindrical specimens of $22 \mathrm{~mm}$ length. In general, only one specimen from each core was used. In the ultimate analyses three sites were employed with 25 specimens from the Nurpur-Kushab road; four sites with 41 specimens from the Nilawan gorge; and two sites with 20 specimens from the Sardahi gorge.

The measurements and the demagnetization procedures were carried out with the standard equipment available. All specimens were measured on magnetometers to obtain both the direction and the intensity of the natural remanent magnetization (NRM). Besides magnetometers of the astatic type mounted in the earth field, a sensitive Czechoslovakian spinner magnetometer, type J R 3, was employed. The use of the astatic magnetometer easily provides the $Q$-value of the specimen: i.e. the ratio of the remanent to the induced magnetization.

The specimens of a particular site very often revealed a remarkably uniform initial NRM intensity. The NRM intensities in $\mathrm{mA} / \mathrm{m}$ vary for the $A$, the $B$, and the $C$ sites between 7.3 and $11.1,4.1$ and 6.2 , and 2.4 and 3.1 , respectively, with mean values of $8.8,5.4$, and 2.8 . The specimens from the Nilawan gorge (sites $\mathrm{D}-\mathrm{G}$ ) and the Sardahi gorge (sites $\mathrm{H}-\mathrm{J}$ ) revealed NRM intensities with respective mean values of $9.6 \mathrm{~mA} / \mathrm{m}$ and $11.6 \mathrm{~mA} / \mathrm{m}$.

In most rocks the NRM is composite and consists of two or more components of magnetization. In order to eliminate the non-characteristic magnetic components, the samples werc subjected to demagnctization procedures. No decisive results could be obtained with the method of partial, progressive demagnetization in alternating magnetic fields. Therefore, progressive, thermal treatments were applied. During heating and subsequent cooling of the 

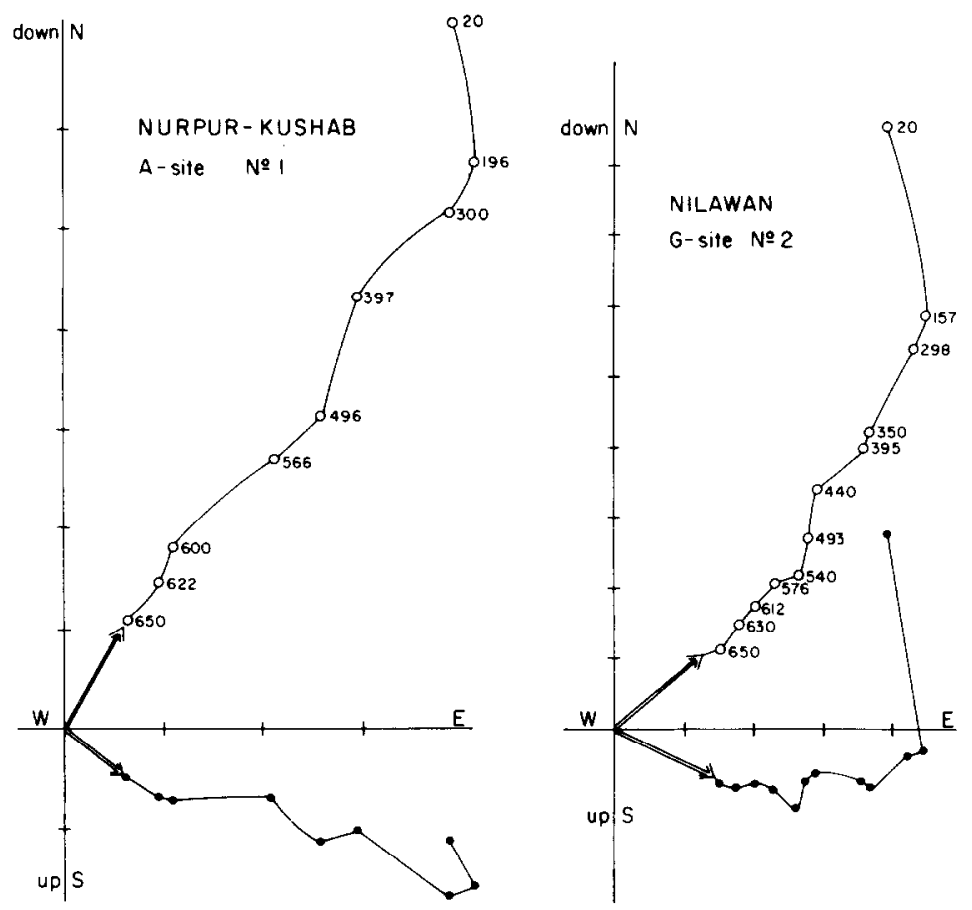

Fig. 3. Demagnetization diagrams of two specimens. The points represent successive positions - in orthogonal projection - of the end of the magnetization vector during progressive, thermal demagnetization. Full and open symbols represent projections on the horizontal plane, and an E-W vertical plane, respectively. Numbers denote the peak values of the applied temperatures in degrees centigrade. On both diagrams each unit on either axis represents $1 \mathrm{~mA} / \mathrm{m}$.

specimens the magnetic field in the furnace was reduced to below about 10 $\mathrm{nT}$. All specimens from the Nurpur-Kushab road (sites A, B, and C) were heated in nine to twelve successive steps up to $680^{\circ} \mathrm{C}$ (Fig. 3). A number of pilot specimens from the Nilawan gorge (sites D, E, F, and G) and from the Sardahi gorge (sites $\mathrm{H}$, and J) were treated partly in twelve, partly in eight successive steps. The remaining specimens were healed in four successive steps up to $680^{\circ} \mathrm{C}$. This minute treatment of the specimens resulted in the removal of the non-characteristic components of magnetization. The paths of the end points of the magnetic vectors during progressive thermal treatment can be inspected on orthogonal projections (Fig. 3). In the majority of the specimens the non-stable magnetizations were eliminated at about $500^{\circ} \mathrm{C}$.

\section{PALEOMAGNETIC DIRECTIONS}

The mean directions of the initial and of the characteristic components of remanent magnetization were calculated for the individual sites. This is compiled in Table I, where also the mean characteristic NRM directions of some combined sites are presented. 


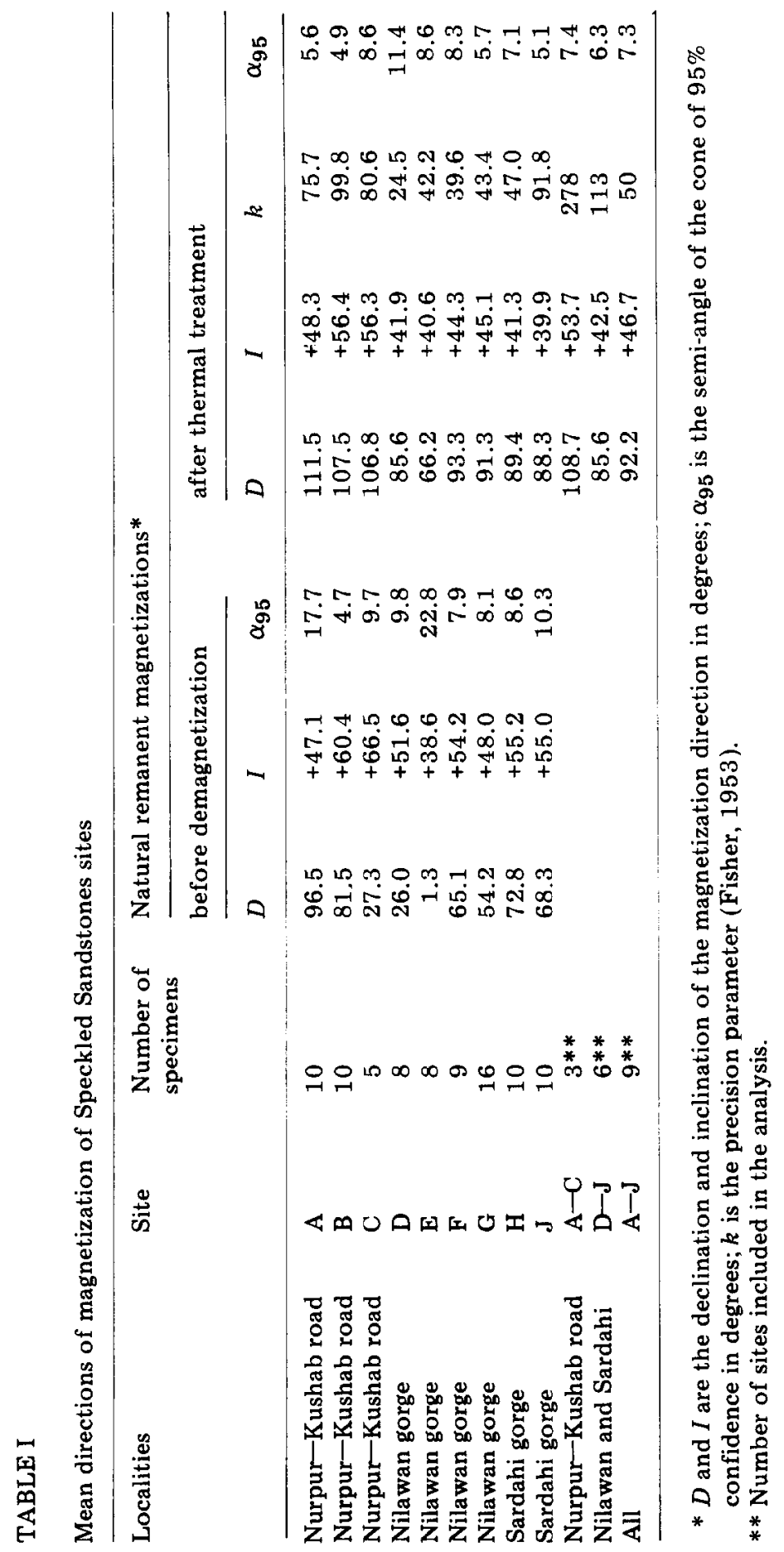




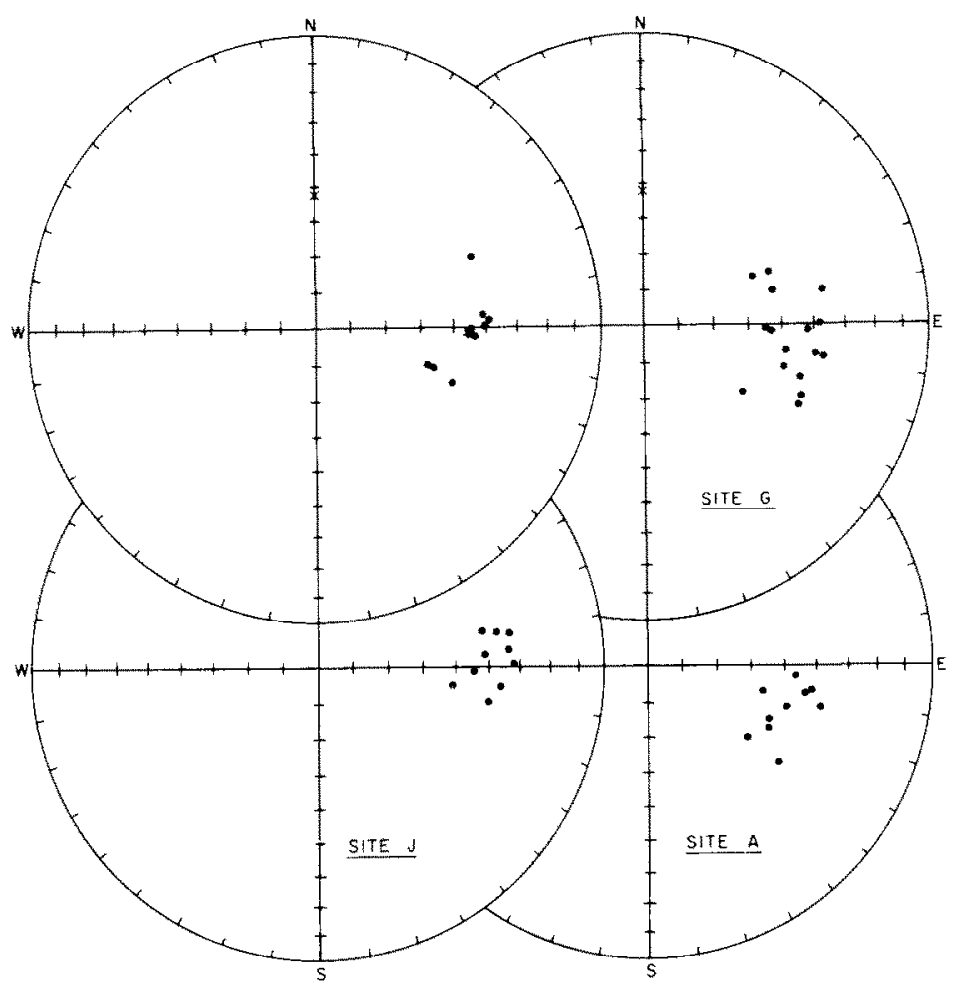

Fig. 4. Equal-area projections with the characteristic directions of magnetization of the specimens of three individual sites after tectonic correction: one of each sampling locality. The projection above left shows the mean direction of magnetization of the individual sites included in this study, as well as the overall mean characteristic direction of magnetization indicated with a star. The north-seeking poles of the directions of all specimens are pointing downwards. The cross denotes the local field direction due to a geocentric axial dipole.

The scatter in the directions of magnetization does not always decrease after partial thermal demagnetization treatments. From Table I it can be learned that at certain sites the scatter even slightly increases after partial demagnetization. Then, the secondary magnetic components of all individual specimens of a particular site are quite conformable in direction and intensity. After removal of the large secondary magnetic components, the remaining intensity of magnetization is rather weak, and consequently small inaccuracies slip in during measurement. The characteristic directions of magnetization of the specimens of three individual sites, one of each locality, are plotted on equal-area projections (Fig. 4).

The mean characteristic direction of magnetization of the combined $A-C$ sites deviates from the value of the mean characteristic direction of the combined D-J sites (Table I). The former direction has a fairly high inclination value which points to a relatively high latitudinal position of the sam- 
pling area during deposition, according to the relation $\operatorname{tg} \lambda=\frac{1}{2} \operatorname{tg} I$, where $\lambda$ is the paleolatitude. This is not in conflict with the stratigraphic position of the sampling sites, being situated only $10-15 \mathrm{~m}$ above the glacial deposits of the Talchir stage. It is possible that the difference in direction between the $A-C$ and the $D-J$ sites is due to the fact that they represent separate rock sequences of the Conularia Beds and the Speckled Sandstones, respectively. Such an age difference between these stages may be reflected in the directions of magnetization. The consequences for the positions of paleomagnetic poles will be discussed below.

\section{DISCUSSION OF THE RESULTS}

The positions of the paleomagnetic poles computed from the combined mean characteristic directions of magnetization are listed in Table II. The pole calculated from the mean direction of magnetization of the combined nine sites is in good agreement with the positions of the paleomagnetic poles derived from rocks of India of the same period (Fig. 5 and Table III).

Because of the difference in their characteristic directions of magnetization, the paleomagnetic poles derived from the combined $A-C$ sites and $D-J$ sites show distinct positions. As said before, this may be due to a difference in age of the corresponding rock sequences. However, no support can be obtained from the Indian paleomagnetic pole positions. The Talchir paleomagnetic pole is situated nearer to the pole ferived from the sites $\mathrm{D}-\mathrm{J}$ than to that obtained from the sites $\mathrm{A}-\mathrm{C}$, probably representing the Speckled Sandstones and the upper part of the Conularia Beds, respectively. This is in contrast with what one would expect in view of the age relations between these sequences of sediment. It is possible that the number of sites included in the paleomagnetic analysis of the Nurpur-Kushab locality is not sufficient to rule out the influence of the secular variation.

The characteristic directions of magnetization of all sites included in this study show reversed polarities; they will fall within the Kiaman Reversed Magnetic Interval covering the whole Permian.

The present result is in agreement with the southward-directed shift of the paleomagnetic pole since the Late Carboniferous with respect to the current position of India. Both the Upper Carboniferous Talchir pole (no. 1) and the Lower Permian Speckled Sandstones pole (no. 2) are situated to the north of the positions of the Mangli (no. 5) and Panchet (no. 6) poles, both with a Late Permian to Early Triassic age (Fig. 5).

The positions of poles no. 3 and no. 4 do not coincide (Fig. 5); both results are based on paleomagnetic studies of Gondwana Red Beds of Permian age on material collected in the same district. However, at pole no. 4 material of higher stratigraphical levels is included in the analysis. The former pole (Wensink, 1968) is based on reversed sites only; the latter pole (Klootwijk, 1975 ) is computed from the results of both reversed sites and normal sites obtained from overlying sediments. This is reflected in the characteristic 


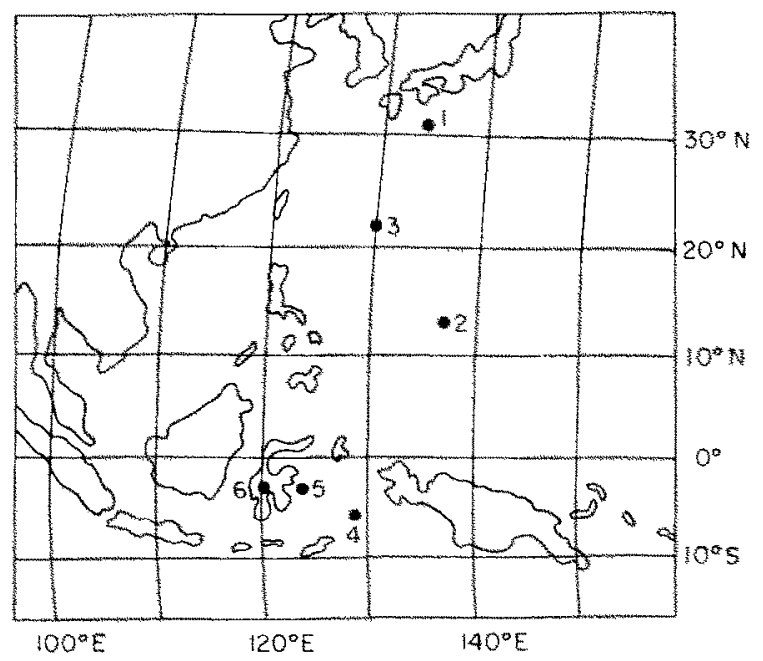

Fig. 5. Map of SE Asia with some paleomagnetic pole positions derived from rocks of Late Carboniferous through Early Triassic age from India and Pakistan. The numbers refer to Table III.

directions of magnetization. Diagrams (Klootwijk, 1975; Fig. 3) clearly show the difference in declination of about $20^{\circ}$ between the reversed sites and the normal sites. In the studies of both Wensink and Klootwijk, the results obtained from the reversed sites agree reasonably well. Klootwijk (1975) explains the discrepancy between poles no. 3 and no. 4 in terms of secondary magnetic components which presumably have been incompletely eliminated from the material of pole no. 3 ; the strong secondary magnetization should be due to former Deccan basalts, which possibly have overlain the Gondwana deposits in the sampling area. It is true that the determination of the characteristic magnetic component often is very difficult (Wensink, 1968). However, a separate presentation of paleomagnetic poles derived from both the reversed and the normal sites is recommendable.

The paleomagnetic data from the Kamthi beds of probably Permian age, reported by Verma and Bhalla (1968), were not considered. In our opinion, the secundary magnetic components from their material have been incompletely eliminated.

The extent of the India-Pakistan subcontinent is not exactly known. The paleomagnetic results of the Cambrian (McElhinny, 1970; Wensink, 1972) from the Salt Range have no definite counterpart in India. Sometimes, a Cambrian age is attributed to the Upper Bhandar sandstones, i.e. the uppermost unit of the Upper Vindhyan System in India, based on lithological correlations with sediments from the Salt Range. From the Upper Bhandar sandstones, paleomagnetic data are available (Athavale et al., 1972; Klootwijk, 1973). And the paleomagnetic results favour a Late Precambrian rather than a Cambrian age for these sandstones; then a steady drift of India can be noted 

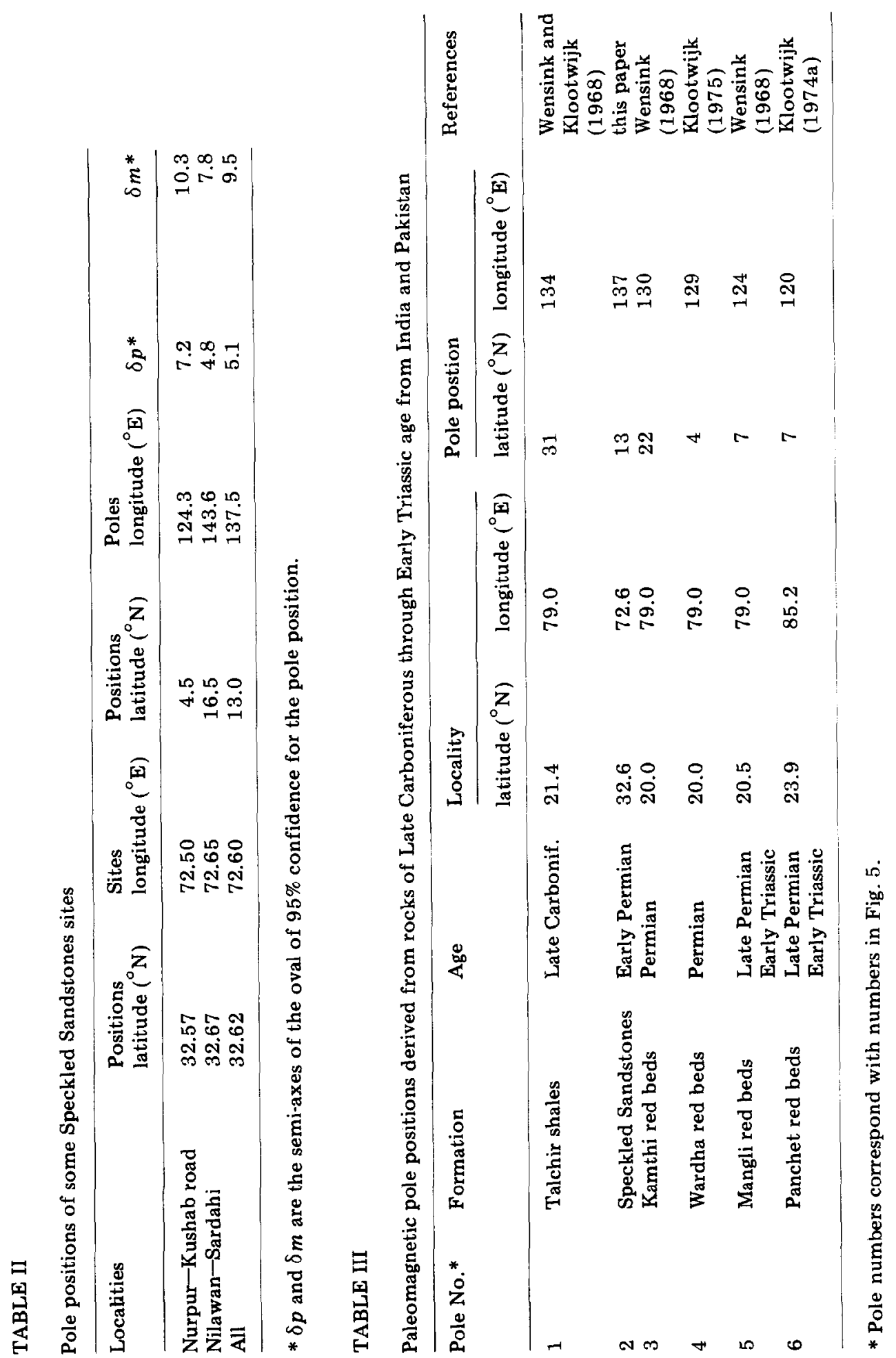
(see Fig. $5 \mathrm{~b}$ in Klootwijk, 1974b) from 645 m.y. at the time of the extrusion of the Malani rhyolites (Athavale et al., 1963) to the Lower Cambrian.

The correlation of the present result from the Salt Range with paleomagnetic data of India from rocks of about the same age favours a relative position between the Salt Range and the Indian part of Gondwanaland that has remained unchanged. Although from a tectonic point of view, $\mathrm{N}-\mathrm{S}$ directed left-lateral transcurrent movements cannot be excluded between the Salt Range and the Indian basement (Abdel-Gawad, 1971), this is not reflected in the paleomagnetic results derived from the Upper Paleozoic sediments of both areas. Nor can support be adduced for the supposed $75^{\circ}$ counter-clockwise rotation of the Salt Range, as recently advocated by Crawford (1974).

\section{ACKNOWLEDGEMENT}

The author is much indebted to the late Prof. M.G. Rutten for his initiative to undertake this work. I am grateful to Prof. J. Veldkamp and Dr. J.D.A. Zijderveld for their interest and help in this study. Thanks are also due to Dr. A.A. Butt and Dr. C.T. Klootwijk for their assistance in the field.

This work was undertaken with the support of the Netherlands Organization for Pure Scientific Research (Z.W.O.). This support is gratefully acknowledged.

\section{REFERENCES}

Abdel-Gawad, M., 1971. Wrench movements in the Baluchistan Arc, and relation to Himalayan-Indian Ocean tectonics. Geol. Soc. Am. Bull., 82: 1235-1250.

Athavale, R.N., Radhakrisnamurty, C. and Sahasrabudhe, P.W., 1963. Paleomagnetism of some Indian rocks. Geophys. J., $7: 304-313$.

Athavale, R.N., Hansraj, A. and Verma, R.K., 1972. Paleomagnetism and age of the Bhander and Rewa sandstones from India. Geophys. J., 28: 499-509.

Balme, B.E., 1970. Palynology of Permian and Triassic strata in the Salt Range and Surghor Range, Pakistan. In: B. Kummel and C. Teichert (Editors), Permian and Triassic of West Pakistan. Dept. Geol. Univ. Kansas, Spec. Publ., 4: 305-453.

Crawford, A.R., 1974. The Salt Range, the Kashmir Syntaxis and the Pamir Arc. Earth Plan. Sci. Lett., 22: 371-379.

Douglass, R.C., 1970. Morphological studies of fusulinids from the Lower Permian of West Pakistan. U.S. Geol. Surv. Prof. Pap., 643 (9): 1-11.

Du Toit, A.L., 1954. The geology of South Africa. Oliver and Boyd, London, 3rd ed.

Fisher, R.A., 1953. Dispersion on a sphere. Proc. R. Soc. London, Ser. A, 217: 295-305.

Klootwijk, C.T., 1973. Paleomagnetism of Upper Bhander sandstones from Central India and implications for a tentative Cambrian Gondwanaland reconstruction. Tectonophysics, 18: 123-145.

Klootwijk, C.T., 1974a. Paleomagnetic results from some Panchet Clay beds, Karanpura coalfield, NE India. Tectonophysics, $21: 79-92$.

Kloulwijk, C.T., 1974b. Paleomagnetic dala from the Precambrian Gwalior Traps, Cenlral India. Tectonophysics, $21: 181-195$.

Klootwijk, C.T., 1975. Paleomagnetism of Upper Permian Red beds in the Wardha Valley, Central India. Tectonophysics, 25: 115-137. 
Krishnan, M.S., 1960. Geology of India and Burma. Higginbothams, Madras, p. 358-369. McElhinny, M.W., 1970. Paleomagnetism of the Cambrian Purple sandstones from the Salt Range, West Pakistan. Earth Plan. Sci. Lett., 9: 149-156.

McElhinny, M.W. and Opdyke, N.D., 1968. The paleomagnetism of some Carboniferous glacial varves from Central Africa. J. Geophys. Res., 73: 689-696.

Pascoe, E., 1959-1963. A Manual of the Geology of India and Burma, Vol. I-III. Govt. of India Press, Calcutta, 2130 pp.

Venkatachala, B.S. and Kar, R.K., 1968. Palynology of the Kathwai shales, Salt Range, West Pakistan. Paleobotanist, 16: 156-166.

Verma, R.K. and Bhalla, M.S., 1968. Paleomagnetism of Tirupati Sandstones of Upper Permian age from Godavary Valley. J. Geophys. Res., 73: 703-709.

Wensink, H., 1968. Paleomagnetism of some Gondwana Red Beds from Central India. Palaeogeogr., Palaeoclim., Palaeoecol., 5: 323-343.

Wessink, H., 1972. The palaeomagnetism of the Salt Pseudomorph Beds of Middle Cambrian age from the Salt Range, West Pakistan. Earth Plan. Sci. Lett., 16: 189-194.

Wensink, H., 1973. The Indian-Pakistan subcontinent and the Gondwana reconstructions based on Palaeomagnetic Results. In: D.H. Tarling and S.K. Runcorn (Editors).

Implications of Continental Drift to the Earth Sciences, I. Academic Press, London, p. $103-116$.

Wensink, H. and Klootwijk, C.T., 1968. The palaeomagnetism of the Talchir. Series of the Lower Gondwana System, Central India. Earth Plan. Sci. Lett., 4: 191-196. 